\title{
KONTRIBUSI SARJANA DAN AKTIVIS DALAM PEMBANGUNAN SERTA PEMBERDAYAAN DESA DI KABUPATEN PAMEKASAN MADURA
}

\author{
Moh. Wardi ${ }^{1}$, Munhari $^{2}$, Ismail $^{3}$, Ali Makki ${ }^{4}$ \\ STAI Nazhatut Thullab Sampang ${ }^{13}$, \\ SMPN 1 Batumarmar Pamekasan ${ }^{2}$, STIS As-Salafiyah Pamekasan ${ }^{4}$ \\ Email: mohwardi84@gmail.com¹, kaktoanberiel88@gmail.com² \\ yajlisismail@gmail.com ${ }^{3}$, alimakkimusaffak@gmail.com ${ }^{4}$
}

\begin{abstract}
This study discusses the contribution of scholars and activists or former campus activists take an active role in building their respective regions. Since the Village Law was passed, many roles can be carried out in accelerating and equitable development between villages and cities. This research uses qualitative methods, namely research procedures that produce descriptive data in the form of written or oral words from people and observed behavior. The source of data in this study rests on human and non-human data sources. The research subject extra Campus activist students, HMI, PMII, GMNI, KAMMI and NGO in Pamekasan Regency. The results showed that Activist Strategy and Contribution to Build Villages in Pamekasan District served and returned to the village through the synergy of young people who had experience and insights on village development and welfare such as Karang Taruna, the establishment of BUMDes, the distribution of local tourism, the establishment of Small Micro Enterprises and Medium (UMKM), etc. The paradigm that needs to be built is actually activists creating opportunities and opportunities for employment, not looking for work.
\end{abstract}

Keywords: Bachelor, Activist, Village Development

\begin{abstract}
Abstrak:
Penelitian ini membahas tentang kontribusi sarjana dan aktivis atau mantan aktivis kampus mengambil peran aktif dalam membangun daerahnya masingmasing. Sejak digulirkan UU Desa, banyak peran yang bisa dilakukan dalam percepatan dan pemerataan pembangunan antara di Desa dan Kota. Penelitian ini menggunakan metode kualitatif, yakni prosedur penelitian yang berusaha mengungkap data berbentuk deskriptif berupa pernyataan tertulis atau lisan dari informan yang diamati. Sumber data atau subjek dalam penelitian ini bertumpu pada sumber data manusia dan non-manusia. Subjek penelitian mahasiswa aktivis ekstra Kampus, HMI, PMII, GMNI, KAMMI dan LSM di Kabupaten Pamekasan. Hasil penelitian menunjukkan bahwa, Strategi Dan Kontribusi Aktivis Membangun Desa Di Kabupaten Pamekasan mengabdi dan kembali ke desa melalui kegiatan sinergi kaula muda yang telah memiliki pengalaman dan wawasan tentang pembangunan dan kesejahteraan desa seperti karang taruna, pembentukan BUMDes, distinasi wisata lokal, pembentukan Usaha Mikro Kecil dan Menengah (UMKM), dll. Paradigma yang perlu dibangun adalah sejatinya aktivis menciptakan kesempatan dan peluang lapangan pekerjaan, bukan mencari pekerjaan.
\end{abstract}

Kata Kunci: Sarjana, Aktivis, Pembangunan Desa 


\section{A. Pendahuluan}

Harian pagi Jawa Pos Radar Madura (selanjutnya disebut JPRM) merupakan salah satu koran dengan tiras terbesar di pulau madura, memiliki pembaca lebih dari 25.000 orang dalam setiap harinya, sehingga memudahkan proses sosialisasi dan suksesnya program dan pelayanan publik, serta memiliki tanggung jawab untuk ikut mengawal pembangunan empat Kabupaten di pulau madura. Madura Awards merupakan salah satu media silaturrahmi Satuan Kerja Pemerintah Daerah empat Kabupaten yang ada di Madura (Sumenep, Pamekasan, Sampang, dan Bangkalan) dalam rangka berkompetisi dibidang prestasi dan inovasi pelayanan publik yang dalam hal ini masing-masing kabupaten mendelegasikan Satuan Kerja Pemerintah Daerah terbaiknya. Selain itu, penyelenggara yang dalam hal ini Jawa Pos Radar Madura memberikan apresiasi bagi pemenang atas kinerja pemerintah kabupaten dan kecamatan, serta memberikan motivasi kepada kabupaten dan SKPD yang lain untuk selalu meningkatkan pelayanan yang prima kepada masyarakat. Madura Award menjadi topik dan opini publik bahkan sorotan lintas kalangan mulai birokrasi, akademisi, jurnalis, dan simpatisan pembaca media cetak (Jawa Pos Radar Madura Group, 27 November 2013)

Dipahami bahwa, penyelenggaraan Madura Award sejak tahun 2013 sampai tahun 2017 merupakan ajang publikasi prestasi masing-masing Kabupaten di Madura dalam rangka mengetahui persamaan dan perbedaannya, kelebihan dan kelemahannya. Pengalaman pendidikan masing-masing Kabupaten sangat bervariasi, diakibatkan karena perbedaan kondisi sosial masyarakat, budaya, dan lainnya. Namun, pada taraf tertentu, prinsip umum yang menjiwai suatu penyelenggaraan pendidikan dapat berlaku secara umum dengan cita-cita tunggal yaitu meningkatkan mencerdaskan rakyat, kesejahteraan bersama, serta meningkatkan pengetahuan demi kualitas dan prestasinya.

Berdasarkan juknis dan pedoman penilaian yang menjadi kesepakatan Dewan Juri Madura Award bahwa sistem penilaian dari prestasi dimaksud berdasarkan tingkat jenjang, prestasi dalam skala Regional, Nasional dan Internasional, Kabupaten Pamekasan selalu menjadi the winner Kabupaten berprestasi dalam kategori pendidikan di ajang Madura Awards 2013-2017. Dengan adanya wadah perlombaan ini, Satuan Kerja Pemerintah Kabupaten 
(SKPD) bisa mengukur peta kekuatan dan kelemahan dalam berbagai sektor utamanya pada sektor pendidikan. Prestasi yang diperoleh Kabupaten Pamekasan memiliki makna dan manfaat, antara lain: pertama, menjadi indikator (simbol) kualitas maupun kuantitas yang dicapai dalam suatu kegiatan. Kedua, pengalaman berharga dan bahan informasi untuk masa yang akan datang sebagaimana Wawancara dengan tim Dewan Juri Madura Awards dari kalangan akademisi keterwakilan dari masing-masing kampus di setiap Kabupaten di Madura, Universitas Trunojoyo Madura (UTM), STAI Nazhatut Thullab Sampang (STAI NATA), Universitas Madura (UNIRA), dan Universitas Wiraraja (UNIJA).

Selain itu, Kabupaten Pamekasan sebagai pemenang, merupakan apresiasi dan publikasi prestasi yang sangat membanggakan dengan nilai yang melampaui tiga kabupaten yang lain. Bahwa prestasi yang diraih Kabupaten Pamekasan merupakan rangkaian dari usaha beberapa elemen masyarakat dan pemerintah, prestasi bukanlah sesuatu yang datang tanpa usaha, namun kerja keras dan semangat yang besar yang akhirnya mengantarkan pada titik akhir yaitu the winner, dan senantiasa motivasi untuk mempertahankan bahkan meningkatkan prestasinya di masa yang akan datang.

Selain itu, Tujuan utama dari kontestasi tersebut adalah meningkatkan hubungan kerja sama di bidang pendidikan khususnya empat Kabupaten di Madura. Mengetahui persamaan dan perbedaannya, kelebihan dan kelemahannya, meminjam istilah orang Manajemen yaitu analisis SWOT (Strenght, Wekness, Opportunity dan Treatmen). Belajar dari keberhasilan pendidikan di Kabupaten Pamekasan, sehingga kita dapat memulai dan mengaplikasikan di Kabupaten yang lain.

Atas dasar keberhasilan Pamekasan sebagai the winner maka Pamekasan masyhur dengan sebutan Kabupaten Pendidikan. Karenanya, secara kuantitas terlihat dari menjamurnya lembaga pendidikan dari unit bawah sampai pendidikan tinggi. Atmosfer kegiatan pendidikan di Kabupaten Pamekasan sangat meningkat pula dalam hal kualitas seperti reward dari penyelenggara even dan kontestasi regional, nasional maupun internasional.

Salah satu implikasi dari beragamnya Pendidikan Tinggi yang beroperasi di Kabupaten Pamekasan adalah kehadiran gerakan mahasiswa sebagai generasi 
muda yang kritis terhadap fenomena sosial ekonomi politik dengan spirit dan semangat yang menggelora untuk perubahan dalam mewujudkan cita-cita dan tujuan nasional. Mahasiswa digolongkan sebagai kaum terpelajar yang mendapatkan pendidikannya di perguruan tinggi (Sarlito Wirawan Sarwono, 1978:39). Perguruan tinggi tidak hanya menghasilkan orang-orang berilmu pengetahuan tinggi, sikap kritis dan gerakan kemahasiswaan, namun hal itu merupakan sosialisasi politik bagian proses kematangan sosial yang membentuk sikap dan perilaku politik melalui pewarisan (Suwondo, 2002:75)

Dalam perspektif historis, pamekasan merupakan kiblat perguruan tinggi di Madura, hal ini dibuktikan dengan hadirnya Perguruan Tinggi Negeri yang semula bernama IAIN Sunan Ampel Pamekasan. Sejak dikeluarkannya Surat Kepres RI No.11 Tahun 1997 tentang status STAIN, Fakultas Tarbiyah IAIN Sunan Ampel Pamekasan konfersi menjadi STAIN Pamekasan, dan pada tahun 2018 alih status kembali menjadi IAIN Madura, selain itu ada UNIRA, UIM dan beberapa PTS lain. Dalam perjalanannya, kampus kampus besar di Pamekasan ini mencetak para aktivis intra dan ekstra, gelombang besar tidak bisa dihindari melalui rekrutmen anggota baru, dilatih dengan beragam training dan kegiatan ilmiah hingga demonstrasi. Disisi lain, para aktivis tentu mengikuti rangkaian kegiatan jadwal kampus yang terstruktur, setiap tahun akademik, kampus mewisuda mahasiswanya $\pm 3000-4000$ sarjana diwisuda setiap tahun dari berbagai kampus di pamekasan.

Hal ini bukanlah tanpa masalah, Dadang Suhardan dalam karyanya di kenal dengan sebutan Unenployment Educated Population (Pengangguran Terdidik). Fenomena dimaksud menjadi problem di negara kita, karena tidak adanya kebijakan yang sinergi antara perencana pendidikan dan perencana ekonomi. Sehingga, dua aspek ini berjalan masing-masing, idealnya lembaga pendidikan ada program planing yang menghasilkan SDM dan tenaga kerja yang handal dan kompeten sebagaimana persyaratan dunia kerja, sementara lembaga ekonomi/industri memanfaatkan SDM yang handal dan profesional produk lembaga pendidikan supaya laju pertumbuhan dan percepatan ekonomi dan kemajuan lembaga pendidikan berjalan terarah dan dinamis (Dadang Suhardan, 2012:60). 
Dalam perspektif Geografis, Pamekasan sebagai centre of Madura, Badan Koordinasi Wilayah (Bakorwil) Madura, menjadikan mobilisasi sosial mahasiswa serta arus transportasi menjadikan daya magnet tersendiri bagi lulusan SMA/MA/Sederajat untuk melanjutkan pada jenjang PT di Pamekasan. Hal ini tentu berdampak kepada lonjakan besar yang tidak bisa dihindari melalui rekrutmen anggota baru para aktivis, dilatih dengan beragam training dan kegiatan ilmiah hingga demonstrasi.

Dalam tinjauan sosial politik ekonomi, Banyaknya aktivis atau mantan aktivis kampus yang enggan pulang kampung dengan alasan yang beragam, mulai dari status dan beban sosial. Serta seluruh kegiatan politik dan ekonomi berpusat di kota, sehingga aktivis atau mantan aktivis kampus yang enggan pulang kampung. Implikasinya terjadi penumpukan (overload) aktivis di lingkungan kota Pamekasan, yang terindikasi berdampak negatif dengan banyaknya organ taktis yang tidak jelas fungsi dan tujuannya.

Hal inilah menjadi dasar pemikiran peneliti untuk mengembangkannya dalam bentuk riset penelitian ini, kami berupaya mencari problematika aktivis, strategi dan solusi alternatifnya dalam pembangunan Desa. Melalui temuan penelitian dan rekomendasi inilah, besar harapan pemerintah, bahwa Para aktivis dimaksud hendaknya mengambil peran aktif dalam membangun daerahnya masing-masing. Sejak digulirkan UU Desa banyak peran yang bisa dilakukan dalam percepatan dan pemerataan pembangunan antara di Desa dan Kota.

\section{B. Landasan Teori}

1. Pendidikan Tinggi, Mahasiswa dan Aktivis

Pendidikan dilingkungan perguruan tinggi diharapkan mampu melahirkan mahasiswa-mahasiswa yang berkualitas dan berkarakter, memiliki keunggulan daya saing serta dapat menjadi tenaga kerja produktif pada berbagai bidang kehidupan. Dengan demikian, mahasiswa hendaknya dapat disiapkan agar mampu mempunyai kualitas daya saing itu guna menghadapi dunia pasar dan persaingan dalam kehidupannya. Namun, upaya mempersiapkan, membangun, dan memberdayakan mahasiswa di lingkungan perguruan tinggi agar mampu berperan serta sebagai pelaku-pelaku aktif pembangunan bangsa Indonesia kelak. Di 
hadapkan pada kenyataan pahit yang membelenggu dunia kemahasiswaan. Begitu banyak persoalan yang membelit para mahasiswa hari ini, seperti maraknya tawuran antara mahasiswa, penyalahgunaan narkoba, seks bebas, plagiat, dan lainlain (Syamsul Kurniawan, 2013: 64). Persoalan lain adalah kepribadian nasional dan ketahanan budaya dikalangan mahasiswa yang semakin luntur, yang disebabkan oleh cepatnya arus informasi global. Hari ini kita menyaksikan kuatnya penetrasi nilai-nilai asing yang tidak sejalan dengan kepribadian bangsa (Syamsul Kurniawan, 2013:64).

Kata "modernisasi" menjelma menjadi "westernisasi", menimbulkan krisis identitas dan moral. Muncul kecenderung yang menggelisahkan bahwa keberadaan agama sebagai "petunjuk" diterima secara acuh tak acuh oleh sebagian kalangan mahasiswa. Kecenderungan lain adalah degradasi semangat kebangsaan, melemahnya idealisme dan patrialisme, serta meningkatnya prakmatisme dan hedonisme dikalangan mahasiswa (Agus Wibowo, 2013:98). Hal ini menjadi PR besar kita, karena bagaimanapun mahasiswa adalah aset yang ditangannyalah masa depan bangsa digantungkan. Apabila permasalahan ini tidak memperoleh perhatian dan penanganan bijaksana, akan memiliki dampak yang luas dan mengganggu keseimbangan serta kesetabilan dalam pembangunan nasional (Agus Wibowo, 2013:98).

Persoalan yang urgen di era globalisasi dalam aspek kehidupan tentu sangat memengaruhi daya saing mahasiswa. Dengan demikian, mahasiswa, diharapkan memiliki keterampilan dan skill yang tinggi untuk mampu bersaing dalam menciptakan kesempatan dan peluang kerja serta memperluas networking yang sedang ditekuni. Banyak faktor yang melatar belakangi persoalan para mahasiswa seperti disebutkan diatas. Namun, secara mudah orang akan menyebut bahwa degradasi karakter itu pemicu utamanya. Boleh jadi, pendidikan karakter di sebagian perguruan tinggi kita baru sebatas wacana sehingga belum mampu diterapkan. Dalam kondisi demikian, memang sukar diharapkan perbaikan karakter para mahasiswa (Mohammad Tohah, 2013:27).

Dengan demikian diperlukan langkah-langkah strategis guna memperbaiki moral dan karakter mahasiswa, dengan menjadikan pendidikan karakter sebagai "ruh" perguruan tingggi. Memang benar bahwa saat ini ada sebagia perguruan 
tinggi telah melaksankan pembelajaran karakter dengan baik. Umumnya, perguruan tinggi tersebut telah memiliki mutu dan kualitas yang baik pula. Namun, masih banyak perguruan tinggi yang sebagian dosennya tidak peduli dengan perilaku mahasiswanya. Mereka terkesan abai, cuwek, dan beranggapan tugasnya hanya mengajar saja, perkara moralitas mahasiswa amburadul dan bobrok itu urusan lain (Mohammad Tohah, 2013:27).

Peran perguruan tinggi tertuang dalam pelaksanaan Tridarma Perguruan Tinggi, yaitu: Pendidikan dan pengajaran, Penelitian, dan Pengabdian masyarakat. Melalui bidang pendidikan, perguruan tinggi diharapkan menjadi transformasi nilai dan ilmu pengetahuan. Dari bidang penelitian, perguruan tinggi diharapkan mampu menemukan dan melahirkan inovasi dalam riset/temuan keilmuan dan kebudayaan. Kegiatan penelitian dan pengembangan mempunyai peranan yang signifikan dalam kemajuan ilmu pengetahuan, seni dan teknologi.

Pengabdian pada masyarakat merupakan serangkaian aktivitas perguruan tinggi diluar perkuliahan kelas, namun menempa diri di masyarakat dalam waktu yang relatif pendek. Kegiatan ini dapat dilakukan atas ikhtiar personal atau kelompok terhadap masyarakat. Melalui pengabdian ini, perguruan tinggi juga akan mendapatkan feedback dari klien/user tentang relevansi ilmu yang diajarkan oleh perguruan tinggi (Zaidamin, 2012:200).

Ketika suatu perguruan tinggi hanya melakukan peran pendidikan semata, maka perguruan tinggi tersebut sedang berfungsi dan berperan seperti sekolah. Ketika suatu perguruan tinggi mendominasi penelitian semata, maka perguruan tinggi tersebut sedang berfungsi dan berperan seperti lembaga survey. Demikian pula jika suatu perguruan tinggi lebih dominan dalam aspek pengabdian pada masyarakat, maka perguruan tinggi itu berfungsi sebagai organisasi sosial atau lembaga syiar/dakwah. Karena itu pelaksanaan ketiga dharma perguruan tinggi menjadi suatu harapan mutu perguruan tinggi yang berimbang. Idealnya ketiga peran Tridarma Perguruan Tinggi tersebut saling sinergis, sehingga secara peguruan tinggi tidak hanya berperan dalam sebagian tridarma dan meninggalkan aspek yang lain. (Indra Djati Sidi, 2017:35).

Dasar Teori yang Dapat Diterapkan dalam Pelaksanaan Tridharma Perguruan Tinggi yaitu: pertama, Lingkar Mutu (Quality Loop) Pendidikan secara 
sistemik berorientasi kepada kompetensi lulusan/out put yang dirumuskan dalam siklus lingkar mutu (Quality Loop). Kedua, on the job assignment, perguruan tinggi melakukan kerja sama dengan industri atau perusahaan yang dapat memberikan kerja nyata kepada lulusannya sehingga proses learning dapat berjalan dan kompetensi kerja standar dapat dipenuhi. Ketiga, Teori atribusi berkenaan dengan analisis terjadinya interaksi di kelas. Dalam konteks proses pembelajaran serta dalam rangka meningkatkan kemampuan atau kompetensi peserta didik maka yang perlu dipertimbangkan adalah perbedaan individual dalam potensilitas, seperti: inteligensi, minat, bakat dan motivasi, serta berbagai tipe belajar peserta didik. (Sri Yuliawati, 2012:29).

2. Gerakan Mahasiswa dalam Teori Michael Foucault "Kekuasaan" dan Teori Antonio Gramsci "Hegemoni”

Eksistensi perguruan tinggi mempunyai peran, kedudukan dan fungsi dalam perkembangan peradaban masyarakat. Proses perubahan kehidupan sosial (social change) di masyarakat yang sangat cepat, menuntut agar posisi dan keberadaan perguruan tinggi benar-benar bemberikan peran dan kontribusi yang nyata (Zaidamin, 2012:200). Tuntutan dan harapan terhadap perguruan tinggi harus mampu menorehkan kualitas dan mutu yang tinggi didukung oleh akuntabilitas. Perguruan tinggi dalam kiprahnya harus menghasilkan lulusan yang berkualitas melalui kegiatan-kegiatan akademik yang telah di programkan. Faktor yang menentukan tingkat keberhasilan dan kualitas suatu perguruan tinggi adalah kemampuan dosen dalam melaksanakan tugas Tridharma Perguruan Tingginya (Suwena dan Kadek Rai, 2017:31).

Gerakan mahasiswa dipengaruhi oleh adanya Kekuasaan dan pengetahuan, kedua hal ini memiliki relasi yang saling berkaitan. Tidak ada kekuasan tanpa pengetahuan, begitu juga sebaliknya tidak ada pengetahuan tanpa kekuasaan, dengan pengetahuan, kekuasan akan beroperasi, dengan kekuasaan maka pengetahuan akan tetap bertahan (K. Bertens, 2001:300). Dengan demikian, lembaga pendidikan formal (dalam konteks ini kampus), juga menjadi bagian dari sistem sosial yang terlibat dalam pembentukan disiplin terhadap individuindividu. Di samping itu, lembaga pendidikan yang idealnya menjadi ajang pembelajaran untuk menanamkan nilai-nilai kesadaran mahasiswa menjadi 
makhluk sosial dan politik juga seringkali menjadi mesin penguasa untuk menanamkan ideologi para penguasa, sehingga kekuasaanya tidak terganggu. Dalam analisis Foucault menjelaskan bahwa kekuasaan bukan melahirkan kepatuhan, melainkan justru melahirkan resistensi. Tidak ada kuasa yang bebas dari oposisi, di mana ada kuasa disitulah resistensi akan lahir (K. Bertens, 2001:300).

Pemikiran Foucault dalam konteks gerakan mahasiswa, manakala kekuasaan (birokrasi) melarang gerakan mahasiswa, maka justru melahirkan resistensi. Semakin kuat kekuasaan itu melakukan hegemoni untuk berkuasa, maka dengan sendirinya semakin besar peluang untuk terjadinya resistensi. Sehingga resistensi merupakan bagian yang tak terpisahkan sebagai anak kandung dari kekuasaan. Ada tiga bentuk kekuasaan, Pertama, Kekuasaan ideologis dengan indoktrinasi sebagai wujud pengungkapan kekerasan dalam aspek psikologis (mental). Kedua, Kekuasaan remuneratif dengan jaminan jabatan, kedudukan, korupsi dll sebenarnya melakukan sebuah kekerasan dalam bentuk fisik dan psikologis. Ketiga, kekuasaan punitif, yaitu melahirkan bentuk intimidasi, penganiayaan, ancaman, tekanan, dan kekerasan secara fisik dan psikologis (Donny Gahral Adian, 2011:102).

Versi lain tentang gerakan mahasiswa yaitu tentang hegemoni didefinisikan Gramsci sebagai kepemimpinan bahwa yang berkuasa memiliki peran dalam segala aspek. Dia mengontraskan hegemoni dengan intimidasi/ancaman yang dilaksanakan oleh kekuatan legislatif atau eksekutif, atau diungkapkan bantuan kepolisian/militer. Gramsci menitikberatkan bahwa "hegemoni" dengan "kepemimpinan budaya". Gramsci ingin memahami bahwa para intelektual yang bekerja di pihak kapitalis mencapai leadership budaya dan persetujuan masyarakat secara umum. (George Ritzer, 2012:476). Hegemoni adalah sebuah rantai kemenangan yang didapat melalui mekanisme konsensus (consenso) dari pada melalui penindasan terhadap kelas sosial lain. Pada hakekatnya adalah upaya untuk menggiring orang agar mampu memahami dan memandang problematika sosial dalam kerangka yang ditentukan.

Penelitian ini ingin melihat bagaimana upaya yang dilakukan birokrasi dalam proses hegemoni kepada mahasiswa terkait kebijakan-kebijakan yang 
dikeluarkan sehingga dapat memperlemah resistensi gerakan mahasiswa. Ada cara yang dilakukan birokrasi untuk melakukan higemonisasi melalui organisasi intra dan ekstra kampus untuk dapat menginternalisasikan nilai-nilai kesadaran menurut birokrasi sehingga dapat memperlemah upaya resistesi yang dilakukan oleh organisasi intra dan ekstra kampus (Moh. Taufik, M. Arif Affandi, 2014:5).

\section{Pembangunan Desa}

Pembangunan pada dasarnya merupakan suatu proses dan upaya yang dilakukan suatu kelompok atau masyarakat secara sistematis untuk mencapai situasi atau kondisi yang lebih baik dari kondisi aktual. Pembangunan perlu mempertimbangkan sumber daya alam (SDA) dan sumber daya manusia (SDM) yang dimiliki. Selain itu, regulasi dalam melakukan pembangunan tersebut juga harus jelas dan sesuai. Berdasarkan mandat UU No. 6 Tahun 2014 tentang Desa, bahwa pembangunan perlu dilaksanakan secara partisipatif. Pembangunan dilakukan desa, dimana desa melakukan pengelolaan pembangunan, mulai dari perencanaan, organizing, pelaksanaan, hingga monitoring dan evaluasi. Disamping itu, selain dapat melakukan pembangunan secara mandiri oleh desa, pembangunan juga dapat melibatkan kerjasama antar desa. Hal ini dilakukan terkait dengan suatu pembangunan yang tidak dapat dilakukan sendiri oleh desa baik dikarenakan oleh keterbatasan dana maupun waktu pelaksanaan.

Tujuan pembangunan desa (desa membangun) adalah meningkatkan kesejahteraan masyarakat desa dan kualitas hidup manusia serta penanggulangan kemiskinan. Cakupan dari kegiatan pembangunan, antara lain:

1. Pemenuhan terhadap kebutuhan dasar;

2. Pembangunan aspek sarana dan prasarana desa;

3. Pengembangan potensi ekonomi lokal;

4. Pemanfaatan SDA yang kontinue.

Prioritas program kegiatan yang dilakukan, dalam rangka:

1. Peningkatan kualitas, mutu dan akses terhadap pelayanan dasar;

2. Pemeliharaan dan pembangunan infrastruktur sumber daya lokal;

3. Pengembangan sektor ekonomi pertanian desa berskala produktif;

4. Pengembangan dan pemanfaatan teknologi tepat guna untuk kemajuan ekonomi; 
5. Peningkatan kualitas ketertiban masyarakat desa berdasarkan kebutuhan, pengelolaan pembangunannya dilakukan oleh seluruh unsur perangkat Desa dengan mempertimbangkan potensi lokal (Lala M Kolopaking, Cila Apriande dan Rilfar Syaharbia. 2016:1).

Dalam UU No 6 tentang Desa, pendekatan pembangunan dilakukan melalui dua konsep yaitu desa membangun dan membangun desa. Fokus pembangunan dalam desa membangun bertujuan untuk peningkatan kualitas pelayanan pemberdayaan dan pembangunan, infrastruktur Desa melalui 2 pendekatan partisipatif. Perencanaan pembangunan Kabupaten dan Kota menjadi acuan dalam desa membangun.

Desa membangun mencakup pemenuhan kebutuhan dasar, pengembangan potensi sosial budaya dan ekonomi lokal, dan pemanfaatan SDA serta lingkungan secara berkelanjutan. Sedangkan aspek yang menjadi prioritas dalam konsep desa membangun antara lain peningkatan kualitas dan akses terhadap pelayanan dasar, pemeliharaan sarana dan lingkungan berdasarkan kompetensi dan SDA lokal yang tersedia, pengembangan agraria berskala produktif, pengembangan dan tekhnologi untuk kemajuan ekonomi, dan peningkatan kualitas ketertiban desa berdasarkan kebutuhan masyarakat desa (Ahmad Erani Yustika, 2015:3).

Pelaksana dalam konsep desa membangun adalah pemerintah desa dan masyarakat desa melalui semangat gotong royong dan memanfaatkan kearifan lokal dan sumberdaya alam desa. Sedangkan fokus pembangunan dalam konsep membangun desa adalah peningkatan kualitas pelayanan, pembangunan, dan pemberdayaan masyarakat desa melalui pendekatan partisipatif dengan tata ruang Kabupaten atau Kota sebagai acuan.

Pelaksana pembangunan dalam konsep membangun desa adalah pemerintah desa, daerah, provinsi, dan pemerintah pusat. Konsep pembangunan yang diamanatkan dalam UU No 6 Tahun 2014 tentang Desa membutuhkan mekanisme perencanaan yang jelas untuk pelaksanaannya. Sehingga diharapkan dapat memberikan panduan kepada desa (pemerintah dan masyarakat) dalam melakukan perencanaan, pelakasanaan, pemantauan dan evaluasi desa dalam melakukan pembangunan. 
Citizen Participation (Partisipasi Masyarakat) merupakan proses dimana setiap individu memliki kesempatan untuk mempengaruhi keputusan publik (setiap individu memiliki suara dalam keputusan publik) dan menjadi bagian dari proses pengambilan keputusan demokratis (Kevin Lang, 1986:10). Pendekatan tradisional (konvensional) saja, saat ini tidak cukup untuk menyusun suatu perencanaan. Pendekatan terintegrasi untuk menyusun perencanaan yang interaktif dengan melibatkan integrasi seluruh pemangku kepentingan terkait dalam mencari informasi yang relevan, berbagi nilai, consensus, dan pada akhirnya dapat menghasilkan aksi yang dapat dikerjakan (feasible) dan dapat diterima (acceptable).

Perbedaan antara perencanaan interaktif dan perencanaan konvensional dapat dilihat pada Tabel, Partisipasi masyarakat merupakan salah satu cara untuk mengurangi ketegangan dan konflik atas keputusan kebijakan publik. Perencana dan partisipasi dapat memperoleh beberapa manfaat dari proses pengikutsertaan masyarakat yang efektif. Proses perencanaan interaktif menggabungkan masukan masyarakat dalam semua tahapan proses perencanaan yang secara teori akan mengarah kepada keputusan yang lebih baik. Partisipasi tentunya memerlukan arahan agar peran serta yang dilakukan efektif, terdapat beberapa gagasan kunci, antara lain:

1. Level partisipasi, Inisiasi dan proses

2. Pengawasan, Kekuatan dan tujuan

3. Peran praktisi, Pemangku kepentingan dan komunitas

4. Perekanan, dan Komitmen

5. Kepemilikan gagasan

6. Kepercayaan diri dan kapasitas (David Wilcox, 1994:78)

\section{Metode Penelitian}

Penelitian ini menggunakan metode kualitatif, yakni prosedur penelitian yang menghasilkan data deskriptif berupa kata-kata tertulis atau lisan dari orangorang dan perilaku yang diamati. Penelitian ini bertujuan untuk mendapatkan gambaran secara holistik tentang kegiatan, ucapan, tulisan, dan atau prilaku dari para aktivis (Lexy Moleong, 2011:4) Penelitian ini mengelaborasikan temuan- 
temuan penelitian di lapangan yang pada akhirnya akan menganalisis secara komprehensif tentang aktivis membangun desa.

Sumber data dalam penelitian ini bertumpu pada sumber data manusia dan non-manusia (Lexy Moleong, 2011:4). Subjek penelitian ditentukan secara Purposive Sampling dikarenakan orientasi penelitian yang dituju adalah para fungsional organisasi yang sudah ditetapkan sebelumnya atau mahasiswa aktivis, masing-masing Ketua Umum Organisasi ekstra Kampus, HMI, PMII, GMNI, KAMMI dan LSM di Kabupaten Pamekasan, Serta Aktivis BEM/DEMA di PTN/PTS/PTKIN/PTKIS di Pamekasan.

Teknik pengumpulan data antara lain: pertama, wawancara mendalam (depth interview) dan Focus Group Discussion (FGD) terhadap aktivis intra dan ekstra kampus, untuk membahas tentang segala problematika yang dihadapi aktivis pamekasaan dan solusi alternatifnya, strategi dan kontribusi aktivis membangun desa di kabupaten pamekasan. Kedua, melalui pengamatan (observation) terhadap segala problematika yang dihadapi aktivis pamekasaan dan solusi alternatifnya, strategi dan kontribusi aktivis membangun desa di kabupaten pamekasan. Ketiga, studi dokumentasi melalui media, catatan arsip, baliho dan brosur di instansi masing-masing organisasi intra dan ekstra (Sugiono, 2010: 309).

Teknik Analisis data pertama, mentranskrip data seluruh hasil wawancara tentang pemberdayaan dan pembangunan Desa secara utuh dan lengkap sebagaimana hasil yang diperoleh di lapangan. Kedua, mereduksi data dengan cara merangkum, memilih topik dan hal yang pokok, memfokuskan hal yang penting, dan membuang hasil catatan yang tidak relevan. Ketiga, penyajian data diantaranya melalui teks naratif, matrik dan bagan. Dalam penelitian ini, data disajikan dalam bentuk teks naratif dan bagan. Keempat, validasi dan trianggulasi data dalam rangka menjaga konsistensi dan meningkatkan pemahaman peneliti terhadap data yang diperoleh. Kelima, penarikan kesimpulan, pada tahap ini peneliti melakukan penarikan kesimpulan berdasarkan hasil analisis data yang telah terkumpul, baik berupa tulisan maupun rekaman. (Lexy Moleong, 2011:330).

Teknik yang digunakan untuk keabsahan data pada penelitian ini antara lain: pertama, perpanjangan keikutsertaaan, hal ini dilakukan dengan memperpanjang 
keikutsertaan dalam penelitian sehingga meningkatkan derajat orisinilitas data yang dikumpulkan. Peneliti mendatangi kantor dan sekretariat dalam frekuensi yang relatif lama, sehingga banyak mempelajari dan dapat menguji ketidak benaran informasi (Lexy Moleong, 2011:330). Kedua, ketekunan pengamatan, langkah ini bertujuan untuk memenuhi kedalaman data dengan melakukan pengamatan yang teliti dan rinci serta berkesinambungan terhadap kegiatan para aktivis. Ketiga, triangulasi adalah teknik mendeteksi keabsahan data dengan mengambil manfaat sesuatu yang lain untuk keperluan pembanding. Penulis melakukan triangulasi, yaitu proses penguatan bukti dari individu-individu yang berbeda, wawancara mendalam (depth interview) dan Forum Group Discussion (FGD) terhadap masing-masing Ketua Umum Organisasi ekstra Kampus, HMI, PMII, GMNI, KAMMI dll. Serta Aktivis BEM/DEMA di PTN/PTS/PTKIN/PTKIS di Pamekasan UNIRA, STAIN/IAIN, UIM, STAI AlKhairat, STAIMU Panyeppen, STIU Al-Mujtama', STIDKIS Al-Hamidy, STIBA Darul Ulum, STEI Madani, STIS Salafiyah, dan OSIS SMA/SMK/MA dan sederajat. Penulis juga melakukan triangulasi antara jenis data hasil observasi, wawancara dan dokumen.

\section{Hasil}

Terpilihnya Kabupaten Pamekasan sebagai the winner dalam setiap perhelatan Madura Awards, maka Pamekasan masyhur dengan sebutan Kabupaten Pendidikan. Karenanya, atmosfer kegiatan pendidikan di Kabupaten Pamekasan sangat meningkat dalam hal kualitas dan kuantitas seperti menjamurnya lembaga pendidikan dari unit bawah sampai pendidikan tinggi. Salah satu implikasi dari beragamnya Pendidikan Tinggi yang beroperasi di Kabupaten Pamekasan adalah kehadiran gerakan mahasiswa sebagai generasi muda yang kritis terhadap fenomena sosial ekonomi politik dengan spirit dan semangat yang menggelora untuk perubahan dalam mewujudkan cita-cita dan tujuan nasional. Mahasiswa digolongkan sebagai kaum terpelajar yang mendapatkan pendidikannya di perguruan tinggi (Sarlito Wirawan Sarwono, 1978:39).

Namun, plus minus tentang kontribusi dan gerakan mahasiswa aktivis ini, masih belum banyak mahasiswa yang menunjukkan prestasi yang baik bahkan 
gagal di bidang akademik. Dalam setiap tahun akademik, masing-masing kampus mewisuda mahasiswanya, tentu hal ini bukanlah tanpa masalah, diantarnya meningkatnya pengangguran produktif (Lulusan Sarjana S1) di pulau Madura secara umum dan khususnya di Pamekasan, \pm 3000-4000 sarjana diwisuda setiap tahun dari berbagai kampus di pamekasan.

Sebagaimana pernyataan Uswatun Hasanah:

Aktivis merupakan seseorang yang secara sadar dan aktif melakukan gerakan perubahan, dengan tugas dan fungsinya melakukan gerakan perubahan untuk terciptanya tatanan masyarakat yang sejahtera. Perbedaan mahasiswa aktivis dan mahasiswa non aktivis terletak pada keaktifan dalam forum ilmiah dan gerakan-gerakan perubahan. Sebagai aktivis, pandangan kampus, masyarakat, dan birokrasi terhadap aktivis memiliki beragam pandangan baik dari segi positif seperti aktivitas kajian, dialog, forum ilmiah, potensi menjadi pemimpin, sebagai agen kontrol kebijakan pemerintah. Sedangkan sisi negatifnya, berupa gerakan demonstrasi yang cenderung anarkis serta keterlambatan lulusan para aktivis dibandingkan dengan mahasiswa non aktivis, serta rivalitas antar aktivis ekstra kampus, lebih-lebih pada even kontestasi pemilihan DPM/DEMA/BEM. Solusi mengembalikan citra positif kalangan aktivis di kampus, masyarakat dan birokrasi adalah dengan cara meningkatkan prestasi, kapasitas keilmuan, melatih jiwa kepemimpinan serta memberikan kontribusi dalam pengembangan SDM dan kampus melalui even kompetisi yang mengatasnamakan individu, delegasi kampus, dan delegasi Kabupaten serta memberikan kontribusi dalam pembangunan kabupaten pamekasan melalui pemberdayaan masyarakat Kabupaten Pamekasan (Uswatun Hasanah, FGD: 17 Mei 2018).

\section{Pendapat Rahmad Faisol dalam Focus Group Discussion (FGD):}

Aktivis memiliki peran penting di masyarakat, bertangung jawab terhadap persoalan dan fenomena sosial kemasyarakatan. Perbedaan mahasiswa aktivis dan mahasiswa non aktivis terletak pemecahan masalah dalam suatu problem. Sebagai aktivis, beragam pandangan kampus, masyarakat, dan birokrasi terhadap aktivis memiliki beragam pandangan baik dari segi positif seperti bisa berkalaborasi dan bermitra dengan masyarakat dan pemerintah. Sedangkan sisi negatifnya, berupa stigma negatif yang sering dibilang menakut-nakuti instansi terkait dan parlemen jalanan. Solusi mengembalikan citra positif kalangan aktivis di kampus, masyarakat dan birokrasi adalah dengan cara mengembalikan citra positif sesuai tugas dan kewajibannya (Rahmad Faisol, FGD: 17 Mei 2018).

Banyaknya aktivis atau mantan aktivis kampus yang enggan pulang kampung sehingga terjadi penumpukan (overload) aktivis di lingkungan kota Pamekasan, yang terindikasi berdampak negatif dengan banyaknya organ taktis 
yang tidak jelas fungsi dan tujuannya. Besar harapan pemerintah, bahwa Para aktivis dimaksud hendaknya mengambil peran aktif dalam membangun daerahnya masing-masing. Sejak digulirkan UU Desa banyak peran yang bisa dilakukan dalam percepatan dan pemerataan pembangunan antara di Desa dan Kota.

Dalam UU No 6 tahun 2014 tentang Desa, pendekatan pembangunan dilakukan melalui dua konsep yaitu desa membangun dan membangun desa. Fokus pembangunan dalam desa membangun bertujuan untuk peningkatan kualitas pelayanan pembangunan, dan pemberdayaan masyarakat desa melalui 2 pendekatan partisipatif. Perencanaan pembangunan Kabupaten dan Kota menjadi acuan dalam desa membangun. Konsep pembangunan yang diamanatkan dalam UU No 6 Tahun 2014 tentang Desa membutuhkan mekanisme perencanaan yang jelas untuk pelaksanaannya. Sehingga diharapkan dapat memberikan panduan kepada desa (pemerintah dan masyarakat) dalam melakukan perencanaan, pelakasanaan, pemantauan dan evaluasi desa dalam melakukan pembangunan. Citizen Participation (Partisipasi Masyarakat) merupakan proses dimana setiap individu memiliki kesempatan untuk mempengaruhi keputusan publik (setiap individu memiliki suara dalam keputusan publik) dan menjadi bagian dari proses pengambilan keputusan demokratis (Kevin Lang, 1986).

Sebagaimana pernyataan Uswatun Hasanah:

Pembangunan Desa adalah upaya meningkatkan kualitas desa dari berbagai aspek kehidupan masyarakat dalam pendidikan, sosial, budaya dan ekonomi. Dalam rangka mencapai perkembangan dan kemajuan desa dimaksud, maka diharapkan para aktivis memiliki inisiatif mengabdi dan kembali ke desa melalui kegiatan sinergi kaula muda yang telah memiliki pengalaman dan wawasan tentang pembangunan dan kesejahteraan desa seperti karang taruna. Namun pada realitasnya, para aktivis kampus enggan kembali ke desa, dikarenakan berbagai hal, status sosial dan eksistensi diri serta kesempatan lapangan kerja di pedesaan. Hal ini diperlukan solusi alternatif adanya kesadaran dan kepedulian para aktivis untuk membangun dan memajukan desa sebagai tanah kelahirannya dengan cara pemahaman tentang regulasi Undangundang dana desa, namun disisi lain kehadiran para aktivis akan mengganggu stabilitas pemerintahan desa melalui peran dan kontrol mahasiswa/aktivis yang dianggap terlalu intern dan privasi khususnya bagi aparat dan perangkat desa. Beragamnya Pandangan perangkat desa terhadap aktivis tentu membutuhkan komunikasi, bukti dan kerja nyata dalam program-program inovatif kemajuan desa, salah satunya melalui padepokan harmoni GILS (Great Indonesian Leader Summit). Untuk menciptakan akuntabilitas dan pemanfaatan dana desa yang tepat guna dan tepat sasaran, maka diperlukan kontrol dan pemantauan 
atau audit internal/eksternal terhadap $\mathrm{RAB}$ dan realisasi program kerjanya, serta pentingnya studi banding tentang layanan dan program agar tidak terjadi kesenjangan yang tajam antara pembangunan di desa dan kota. Sebagai bentuk apresiasi bagi para aktivis, tentang peluang dan kesempatan pekerjaan di Desa saat ini, maka paradigma yang perlu dibangun adalah sejatinya aktivis menciptakan kesempatan dan peluang lapangan pekerjaan, bukan mencari pekerjaan (Uswatun Hasanah, FGD: 17 Mei 2018).

Pendapat Afifuddin Tirmidzi dalam Focus Group Discussion (FGD):

Perlu adanya gerakan aktivis membangun desa, Kehadiran para aktivis di desa membuka peluang pembangunan desa, membuka skat kesenjangan SDM di desa dan kota. Melalui peran dan kontrol mahasiswa/aktivis terhadap dana desa, gagasan kreatif melalui forum diskusi dengan menawarkan konsep yang bermutu seperti pemanfaatan potensi desa, pengembangan UMKM serta BUMDes (Afifuddin Tirmidzi, FGD: 17 Mei 2018).

Pendapat Fausi dalam Focus Group Discussion (FGD):

Kehadiran para aktivis di desa melalui peran dan kontrol mahasiswa/aktivis terhadap dana desa, Konsep pembangunan tentang Desa membutuhkan mekanisme perencanaan yang jelas untuk pelaksanaannya. Sehingga diharapkan dapat memberikan panduan kepada desa (pemerintah dan masyarakat) dalam melakukan perencanaan, pelakasanaan, pemantauan dan evaluasi desa dalam melakukan pembangunan. Melalui forum diskusi inilah, dengan menawarkan konsep yang bermutu maka kehadiran aktivis sangat dinantikan dalam percepatan pembangunan desa (Fausi, FGD: 17 Mei 2018).

\section{E. Pembahasan}

Organisasi mahasiswa ekstra kampus ini muncul pada zaman orde baru yang menerapkan sistem NKK/BKK (Normaslisasi Kehidupan Kampus/Badan Koordisasi Kemahasiswaan) di dalam seluruh kampus di Indonesia, termasuk kampus di Kabupaten Pamekasan. Masing-masing organisasi ekstra kampus PMII, HMI, IMM, GMNI dan KAMMI di Pamekasan mengalami pasang surut. Hal ini dapat dilihat dari dinamika proses pengkaderan, loyalitas kader, kepolitikan dikampus. Dalam dinamika sistem perkaderan masing-masing organisasi ekstra kampus bersifat bertahap.

Tahapan pengkaderan tersebut yakni: (1) PMII mulai dari Masa Penerimaan Anggota Baru (MAPABA), Pelatihan Kader Dasar (PKD), dan Pelatihan Kader Lanjutan (PKL)., (2) HMI mulai masa perkenalan calon anggota (MAPERCA), 
Latihan Kader I (Basic Training), Latihan Kader II (Intermediate Training), Dan Latihan Kader III (Advanced Training)., (3) IMM mulai Masa Ta'aruf (MASTA), Darul Arqam Dasar (DAD), Darul Arqam Madya (DAM), dan Darul Arqam Paripurna (DAP), (4) KAMMI Proses pengkaderan mulai dari Pra Daurah Marhalah (DM), Daurah Marhalah I (DM), Daurah Marhalah 2 (DM 2), dan Daurah Marhalah 3 (DM3) Kesemua tahapan tersebut di sertai Follow up yang bertujuan pemahaman terhadap anggota baru. Selain itu juga ada kegiatan-kegitan khusus untuk menjaga loyalitas kadernya masing-masing organisasi mahasiswa ekstra kampus di Pamekasan. Organisasi mahasiswa ekstra kampus sangat berperan dalam pembekalan karakter mahasiswa yang berkualitas. Dalam hal ini, kampus menawarkan banyak hal bagi mahasiswa, mulai dari sisi akademis dan organisatoris, antara lain: Pertama, Melatih Leadership, mahasiswa yang ikut organisasi kampus umumnya memiliki sikap dan karakter leadership yang melebihi non aktivis.

Kedua, kekuatan jaringan dan networking dari level lokal, regional, dan Nasional. Organisasi ekstra kampus mencetak kader-kader yang berkualitas di tengah masyarakat. Sebagai contoh dari kalangan aktivis dari PMII Bapak Badrut Tamam menjadi Bupati terpilih Kabupaten Pamekasan periode 2018-2022, Dari HMI Bapak Raja'ie menjadi Wakil Bupati terpilih Kabupaten Pamekasan periode 2018-2022.

Beragam stigma negatif yang dari internal aktivis sendiri, pihak eksternal, pihak kampus, masyarakat, dan birokrasi terhadap para aktivis seperti keterlambatan lulusan para aktivis dibandingkan dengan mahasiswa non aktivis, keterlibatan aksi dan demontrasi parlemen jalanan, mengganggu stabilitas kinerja birokrasi dengan beragam intimidasi dan pemerasan dari para aktivis, hal ini sedikit terjawab, bahwa selama menjadi mahasiswa dan aktivis, mereka belajar tentang leadership yang disiapkan menjadi pemimpin dimasa yang akan datang.

Mengembalikan citra positif para aktivis dengan cara meningkatkan prestasi, kapasitas keilmuan, melatih jiwa kepemimpinan serta memberikan kontribusi dalam pengembangan SDM di Kabupaten Pamekasan menjadi solusi alternatif yang dapat memberikan kontribusi dalam pembangunan kabupaten Pamekasan melalui keterlibatan dalam tria politica eksekutif, legislatif, dan 
yudikatif, hal ini dilakukan dalam rangka kemajuan dan kesejahteraan masyarakat di Kabupaten Pamekasan. Dalam konteks pembangunan Desa, bahwa hadirnya Undang-Undang Desa mulai mengubah paradigma dan pola pikir masyarakat desa. Desa mandiri adalah harapan yang diidamkan dari semua desa saat ini, dimana desa dapat mengelola, memanfaatkan dan memberdayakan segala sumber daya, serta potensi yang dimiliki untuk kepentingan dan kesejahteraan warganya.

Hal tersebut mulai menarik minat masyarakat desa terutama mereka yang aktivis jenjang S1, jauh sebelum ini, banyak orang berpendapat bahwa urbanisasi sukses di luar adalah hal yang paling membanggakan. Namun paradigma ini mulai memudar, mengabdi dan bekerja di desa merupakan suatu kebanggaan tersendiri karena bisa membangun dan memajukan desanya sendiri melalui wahana Badan Usaha Milik Desa (Bumdes) di Kabupaten Pamekasan.

Sebanyak 128 dari total 178 desa yang ada di Kabupaten Pamekasan, Jawa Timur hingga kini belum memiliki Badan Usaha Milik Desa (BUMDes) (Ahmad Faisol, 2018). terdapat 50 desa yang memiliki BUMDes dari total 178 desa yang tersebar di 13 kecamatan di Pamekasan. Sebanyak 128 desa lainnya belum memiliki BUMDes. Ada beberapa kendala yang dihadapi para aparat desa di Pamekasan, sehingga belum membentuk BUMDes. Antara lain, karena kendala sumber daya manusia (SDM) yang ada di tingkat desa. "Saat ini masih banyak aparat desa yang belum paham tentang bagaimana prosedur membentuk BUMDes, sistem kinerja dan manfaatkan terhadap pengembangan ekonomi desa," ujarnya, menjelaskan.

Kondisi ini, menyebabkan banyak kepala desa di Pamekasan lambat dalam membentuk BUMDes. Padahal, keberadaan unit usaha ekonomi di tingkat desa berupa BUMDes itu, merupakan amanat dari Undang-Undang Nomor 6 Tahun 2014 tentang Desa yang diperkuat oleh Peraturan Pemerintah Republik Indonesia Nomor 43 Tahun 2014 tentang Peraturan Pelaksanaan UU Nomor 6 Tahun 2014. Dibanding tahun 2017, jumlah desa yang telah memiliki BUMDes ini telah bertambah. Sebab, pada 2017, jumlah desa yang tersebar di 13 kecamatan di Kabupaten Pamekasan kala itu baru sebanyak 26 desa yang membentuk BUMDes. "Jadi, kalau dibandingkan dengan 2017, bertambah 24 desa. Tahun 2017 BMUDes di Pamekasan hanya 26 desa, dan tahun 2018 sebanyak 50 desa, 
atas dasar inilah, diharapkan adanya peran aktif para pendamping desa untuk mengarahkan para aparat desa lebih proaktif dalam mengarahkan para aparat desa untuk segera membentuk BUMDes.

Kompetisi antar Desa saat ini sedang giat membangun dan berinovasi, apabila di dukung dengan sumber daya manusia yang berkualitas, maka desa akan semakin maju dan mandiri. Desa memerlukan para sarjana dan aktivis, gerakan kembali dan membangun desa membawa perubahan kebaikan bagi desa sebagai pelopor, inovator dan pendamping. Socio-oriented yaitu usaha yang memiliki kebermanfaatan pada manusia yang lain (khairu an-nas anfauhum li an-nas). Ketika semua aktivis dan sarjana membuka yayasan pendidikan, maka terdapat inovasi dan pelopor mendirikan yayasan social-preneur yaitu kampung gembala di waru yang dilakukan oleh Miftah, dan ternak sapi yang dilakukan oleh Imam. Perlu diketahui bahwa, kampung gembala dan ternak sapi dimaksud dengan niat akan mengurangi tingkat pengangguran serta menambah kesejahteraan ekonomi masyarakat. Asumsi dasarnya adalah, ketika populasi ternak, sebanding dengan populasi masyarakat didaerah/tempat tertentu, maka tingkat pengangguran berkurang, dan tingkat kesejahteran masyarakat di sekitar kita juga meningkat. Dalam hal ini social-preneur yang digagas oleh mereka, mampu mempekerjakan masyarakat dan tetangga sekitarnya menjadi pencari pakan ternak, ada juga yang bertugas menjual hewan ternaknya, juga ada yang bertugas menjadi tukang sebelih hewan ternak di areal tempat pemotongan hewan ternak. Lebih dari itu, social-preneur rintisan beliau mampu meningkatkan nilai-nilai yang terdapat dalam kegiatan entrepreneur.

Realitas yang terjadi saat ini adalah, masyarakat yang sudah mengenyam pendidikan tinggi saja, masih dihadapkan persoalan peluang kerja dan kesempatan kerja. Analogi sederhananya adalah, kalau saja masyarakat terdidik masih memikirkan tentang lapangan pekerjaan, apalagi mereka yang tidak pernah mengenyam pendidikan dan keterampilan lainnya. Fenomena ini kemudian muncul istilah Unenployment Educated Population (Populasi Pengangguran Terdidik). Fenomena ini dapat dijumpai di Negara berkembang karena tidak adanya formula dalam mensinkrokan/sinergi antara dimensi ekonomi dan pendidikan. Akibatnya, masing-masing berjalan terpisah tanpa saling melengkapi 
dan menguntungkan. Idealnya, lembaga pendidikan mencetak tenaga kerja sebagaimana tuntutan dunia kerja, sementara lembaga ekonomi memaksimalkan sumber daya manusia profesional, sehingga sistem ekonomi negara kita kuat dan stabil.

Unenployment Educated Population (Populasi Pengangguran Terdidik) fenomena yang terjadi di negara berkembang, antara lain karena faktor: pertama, penyelenggaraan pendidikan hanya sekedar amanat undang-undang, dan janji politik pemerintah, lebih dari itu, bahwa misi tersebut adalah dalam rangka mencerdaskan kehidupan bangsa. Kedua, penyelenggaraan pendidikan bersifat formalitas dan administratif semata, idealnya adalah berorientasi pada pembangunan nasional bangsa. Ketiga, pendidikan bukanlah semata-mata pemenuhan ijazah semata, namun harus berorientasi pada memenuhan pembangunan nasional bangsa. Keempat, minimnya sinergi dan komonikasi antara sektor pendidikan dan sektor ekonomi/tenaga kerja (Dadang Suhardan dkk, 2012:61).

Yayasan social-preneur yaitu kampung gembala di waru yang dilakukan oleh Bapak Miftah, dan ternak sapi yang dilakukan oleh Bapak Imam di Desa Pangereman sampang menjadi langkah solutif mengurangi tingkat pengangguran serta menambah kesejahteraan ekonomi masyarakat. Asumsi dasarnya adalah, ketika populasi ternak, sebanding dengan populasi masyarakat didaerah/tempat tertentu, maka tingkat pengangguran berkurang, dan tingkat kesejahteran masyarakat di sekitar kita juga meningkat.

Kepada pihak pemerintah, dalam hal ini pemerintah kabupaten Pamekasan diharapkan memberikan dukungan melalui fasilitas, peluang dan kesempatan peluang kerja di desa semisal pendamping desa, pendamping keluarga harapan dll yang bisa dijadikan ruang aktivitas bagi para mantan aktivis setelah kembali ke desa. Selain itu, pemerintah kabupaten Pamekasan diharapkan memberikan dukungan melalui Perda tentang Desa. Dimana jabatan dan struktur desa mencantumkan syarat minimal S1 yang dibuktikan dengan surat keterangan aktif dalam kegiatan kemahasiswaan atau kegiatan sosial kemasyarakatan lainnya. Serta apresiasi dan pemberian reward kepada Desa yang meraih even kontestasi semisal Madura Award dll. 
Kepada pihak kampus, bahwa program KKN/KPM (Kuliah Pengabdian kepada Masyarakat) diperkuat melalui metode riset yang keberlanjutan seperti Partisipatori Action Research (PAR) pemetaan tentang problem dan potensi desa, serta tindak lanjut pada MoU dengan Kepala Desa terkait untuk realisasi dari kegiatan Kuliah Pengabdian Masyarakat berbasis riset dimaksud.

Kepada pihak aktivis, mengharap kesadaran kolektif, esensi arti pengabdian kepada desa, Desa memerlukan para sarjana dan aktivis, gerakan kembali dan membangun desa membawa perubahan kebaikan sebagai pelopor, inovator dan pendamping pembangunan di Desa.

Kepada Kepala Desa dan perangkatnya, bahwa hadirnya Undang-Undang Desa mulai mengubah paradigma dan pola pikir masyarakat desa. Desa mandiri adalah harapan yang diidamkan dari semua desa saat ini, dimana desa dapat mengelola, memanfaatkan dan memberdayakan segala sumber daya, serta potensi yang dimiliki untuk kepentingan dan kesejahteraan warganya.

Hal tersebut mulai menarik minat masyarakat desa terutama mereka yang aktivis jenjang S1, jauh sebelum ini, banyak orang berpendapat bahwa urbanisasi sukses di luar adalah hal yang paling membanggakan. Namun paradigma ini mulai memudar, mengabdi dan bekerja di desa merupakan suatu kebanggaan tersendiri karena bisa membangun dan memajukan desanya sendiri melalui wahana Badan Usaha Milik Desa (Bumdes) di Kabupaten Pamekasan.

\section{F. Kesimpulan}

Problematika Yang Dihadapi Aktivis Pamekasan Dan Solusi Alternatifnya meliputi: stigma negatif baik dari internal aktivis sendiri, pihak eksternal pihak kampus, masyarakat, dan birokrasi berupa keterlambatan lulusan para aktivis dibandingkan dengan mahasiswa non aktivis, rivalitas antar aktivis ekstra kampus, lebih-lebih pada even kontestasi pemilihan DPM/DEMA/BEM, keterlibatan aksi dan demontrasi, parlemen jalanan, mengganggu stabilitas kinerja birokrasi dengan bergam intimidasi dan pemerasan dari para aktivis dan LSM. Solusi alternatifnya adalah, mengembalikan citra positif para aktivis dan LSM dengan cara meningkatkan prestasi, kapasitas keilmuan, melatih jiwa kepemimpinan serta memberikan kontribusi dalam pengembangan SDM dan kampus melalui even 
kompetisi yang mengatasnamakan individu, delegasi kampus, dan delegasi Kabupaten serta memberikan kontribusi dalam pembangunan kabupaten pamekasan melalui pemberdayaan masyarakat Kabupaten Pamekasan.

Strategi Dan Kontribusi Aktivis Membangun Desa Di Kabupaten Pamekasan diharapkan para aktivis memiliki inisiatif mengabdi dan kembali ke desa melalui kegiatan sinergi kaula muda yang telah memiliki pengalaman dan wawasan tentang pembangunan dan kesejahteraan desa seperti karang taruna, pembentukan BUMDes, distinasi wisata lokal, pembentukan Usaha Mikro Kecil dan Menengah (UMKM), dll maka paradigma yang perlu dibangun adalah sejatinya aktivis menciptakan kesempatan dan peluang lapangan pekerjaan, bukan mencari pekerjaan.

\section{Daftar Pustaka}

Adian, Donny Gahral. 2011. Setelah Marxisme Sejumlah Teori Ideologi Kontemporer. Jakarta: Koekoesan.

Bertens, K. 2001. Filsafat Barat Kontemporer Prancis. Jakarta: Gramedia.

Faisol, Ahmad. Wawancara, Kepala Dinas Pemberdayaan Masyarakat Kab. Pamekasan https://id.wikipedia.org/wiki/IAIN_Madura\#Sejarah diakses pada tanggal 5 Juli 2018.

Jawa Pos Radar Madura Group, 27 November 2013.

Kolopaking, Lala M. Cila Apriande dan Rilfar Syaharbia. 2016. Mekanisme Perencanaan Desa Membangun dan Membangun Desa. Working Paper Pusat Studi Pembangunan Pertanian Pedesaan Lembaga Penelitian Dan Pengabdian Kepada Masyarakat Institut Pertanian Bogor, Vol. 1 No. 1 Januari.

Kurniawan, Syamsul. 2013. Pendidikan Karakter. Yogyakarta: Ar-Ruzz Media.

Lang, Kevin. 1986. Planning Analysis: The Theory of Citizen Participation di dalam Silabus Perkuliahan Planning Analysis. USA: University of Oregon.

Moleong, Lexy. 2011. Metodologi Penelitian Kualitatif. Bandung: Remaja Rosdakarya.

Ritzer, George. 2012. Teori Sosiologi dari Sosiologi Klasik sampai Peerkembangan Terakhir Postmodern. Yogyakarta: Pustaka Pelajar.

Sarwono, Sarlito Wirawan. 1978. Perbedaan antara Pemimpin dan Aktivis dalam Gerakan Mahasiswa, Suatu Studi Psikologi Sosial (Disertasi). Jakarta: Fakultas Psikologi Universitas Indonesia.

Sidi, Indra Djati. 2017. "Menuju Masyarakat Belajar" Jurnal Paramadina Jakarta, vol. 7, No.1, Juli.

Sugiono, 2010. Metode Penelitian Pendidikan (Pendekatan Kuantitatif, Kualitatif, dan $R \& D)$. Bandung: Alfabeta. 
Suhardan, Dadang dkk, 2012. Ekonomi dan Pembiayaan Pendidikan. Bandung, Alfabeta.

Suwena dan Kadek Rai, 2017. “The Administrator's Production Function sebagai Sebuah Pendekatan Penilaian Produktivitas Pelaksanaan Proses Belajar Mengajar Dosen pada Perguruan Tinggi”, Ejournal undiksha, Vol, 7 N0. 1, Juli.

Suwondo, 2002. Gerakan Mahasiswa Bandar Lampung (Disertasi). Jakarta: Fakultas Ilmu Sosial dan Ilmu Politik Universitas Indonesia.

Taufik, Moh. \& M. Arif Affandi, 2014. Resistensi Gerakan Mahasiswa Terhadap Kapitalisasi Pendidikan (Studi Organisasi Eksternal Kampus di Unesa), Paradigma.

Tohah, Mohammad. 2013. Pendidikan Agama Islam Berbasis Karakter di Perguruan Tinggi. Surabaya: Pena Salsabila.

Wawancara dengan tim Dewan Juri Madura Awards dari kalangan akademisi keterwakilan dari masing-masing kampus di setiap Kabupaten di Madura, Universitas Trunojoyo Madura (UTM), STAI Nazhatut Thullab Sampang (STAI NATA), Universitas Madura (UNIRA), dan Universitas Wiraraja (UNIJA).

Wibowo, Agus. 2013. Pendidikan Karakter Di perguruan Tinggi; Membangun Karakter Mahasiswa di Perguruan Tinggi. Jakarta: Gramedia.

Wilcox, David. Community participation and empowerment putting theory into practice. RRA Notes (1994), Issue 21, pp. 78-82. IIED, London.

Wirawan Sarwono, Sarlito. 1978. Perbedaan antara Pemimpin dan Aktivis dalam Gerakan Mahasiswa, Suatu Studi Psikologi Sosial (Disertasi). (Jakarta: Fakultas Psikologi Universitas Indonesia.

Yuliawati, Sri. 2012. "Kajian Implementasi Tridharma Perguruan Tinggi Sebagai Fenomena Pendidikan Tinggi di Indonesia” Jurnal Pendidikan No. 318, Maret.

Yustika, Ahmad Erani. 2015. Sistem Membangun Desa. Jakarta: Kementerian Desa, Pembangunan Daerah Tertinggal Dan Transmigrasi Republik Indonesia.

Zaidamin. 2012. "Tri Dharma Perguruan Tinggi”, Jurnal Tadris IAIN Sunan Ampel Surabaya, Vol, 7 No. 2, Desember.

\section{Focus Group Discussion (FGD)}

Abdul Qorib, Focus Group Discussion (FGD), Pamekasan, 17 Mei 2018. Afifuddin Tirmidzi, Focus Group Discussion (FGD), Pamekasan, 17 Mei 2018. Badrut Tamam, Focus Group Discussion (FGD), Pamekasan, 17 Mei 2018.

Fausi, Focus Group Discussion (FGD), Pamekasan, 17 Mei 2018.

Hayatin, Focus Group Discussion (FGD), Pamekasan, 17 Mei 2018.

Mabrurah, Focus Group Discussion (FGD), Pamekasan, 17 Mei 2018.

Rahmad Faisol, Focus Group Discussion (FGD), Pamekasan, 17 Mei 2018.

Sanjania Hasanah, Focus Group Discussion (FGD), Pamekasan, 17 Mei 2018.

Uswatun Hasanah, Focus Group Discussion (FGD), Pamekasan, 17 Mei 2018.

Yuli Anisah, Focus Group Discussion (FGD), Pamekasan, 17 Mei 2018.

Jurnal Darussalam; Jurnal Pendidikan, Komunikasi dan Pemikiran Hukum Islam Vol. X, No 2: 280-303. April 2019. ISSN: 1978-4767 (Cetak), ISSN: 2549-4171 (Online)

Terakreditasi Nasional. SK. No.21/E/KPT/2018 